\title{
Female reproductive patterns in nonhibernating bats
}

\author{
D. P. Jerrett* \\ Department of Anatomy, College of Medicine, The University of Arizona, Tucson, Arizona, \\ U.S.A.
}

\begin{abstract}
Summary. The major reproductive events in the oestrous cycles of nonhibernating mega- and microchiropteran species are reviewed. However, special attention is given to the reproductive biology of the temperate North American species, Tadarida brasiliensis mexicana (Molossidae), the Mexican free-tailed bat, which expresses dextral uterine and ovarian dominance. Only the larger right ovary is capable of producing an ovulatory follicle and the left has long been considered atrophic. In order to elucidate the normal oestrous cycle and define the structural and functional characteristics of the ovaries of this nonhibernating bat several analytical techniques were utilized. These included light microscopic analysis, histochemical localization of $\Delta^{5}$-3 $\beta$-hydroxysteroid dehydrogenase (HSD) activity, and radioimmunoassay of seasonal plasma progesterone levels.

Interstitial tissue was found in both ovaries, but the left was almost entirely an interstitial organ. Histochemical analysis demonstrated that the gonads have seasonally varying amounts of $\Delta^{5}-3 \beta$-HSD localized either in the thecal cells of the Graafian follicle or in the interstitium.

The corpus luteum persisted throughout gestation, reaching maximum development just prior to parturition. Circulating progesterone levels correlated directly with luteal gland size and peaked at $106 \mathrm{ng} / \mathrm{ml}$ when the corpus luteum was largest.
\end{abstract}

\section{Introduction}

The order Chiroptera is one of the more diverse taxa of the class Mammalia and as such exhibits numerous specializations in female reproductive morphology and cyclicity. Included are the members of a group of nonhibernating bats which virtually have world-wide distribution and are represented by both mega- and microchiropteran species. The reproductive cycles can be categorized according to patterns which comprise (1) aseasonally polyoestrous, (2) seasonally polyestrous and (3) seasonally monoestrous events to include unique specializations such as menstruation, prolonged development, delayed embryonic development, delayed implantation and ovarian/uterine asymmetry.

Examples of polyoestrous bats with unrestricted breeding seasons are Desmodus rotundus (Desmodontidae) (Wimsatt \& Trapido, 1952; Quintero \& Rasweiler, 1974), Taphozous longimanus (Emballonuridae) (Gopalakrishna, 1955) and Pipistrellus mimus mimus (Vespertilionidae) (Gopalakrishna, Thakur \& Madhavan, 1975). All stages of pregnancy have been noted throughout the year with lactating and pregnant females frequently observed. Desmodus also expresses a slow rate of early embryonic development, protracted transport of the zygote through the oviduct, loss of the zona pellucida in the oviduct and involution of the corpus luteum culminating in menstruation. All species give birth to only one young with each successful pregnancy.

\footnotetext{
* Present address: Department of Anatomy, School of Dental Medicine, University of Pittsburgh, Pittsburgh, Pennsylvania 15261 , U.S.A.
} 
Some seasonally polyoestrous tropical species, those with well-established bi- or trimodal breeding sequences, include the pteropids Epomops franqueti (Okia, 1974a), Rousettus aegyptiacus (Mutere, 1968), Rousettus leschenaulti (Gopalakrishna \& Choudhari, 1977), Cynopterus brachyotis (Liat, 1970), Cynopterus sphinx gangeticus (Gopalakrishna \& Murthy, 1960), and the Eastern epauletted bat Epomophorus anurus (Okia, 1974b). All yield one young at each parturition date from an extended gestation period (Asdell, 1964). Also contained in this category are a vast number of frugivorous bats of the family Phyllostomatidae (Fleming, Hooper \& Wilson, 1972) which display bimodal breeding behaviour and typically produce two young annually from ova alternately expelled from each ovary. Several species, Artibeus jamaicensis (Fleming, 1971), Carollia perspicillata (Bonilla \& Rasweiler, 1974) and Glossophaga soricina (Rasweiler, 1972, 1974), have been reported with unique physiological manifestations accompanying their reproductive cycles. Artibeus jamaicensis exhibits a prolonged embryonic diapause of approximately $2 \frac{1}{2}$ months during the first oestrus which coincides with the height of the rainy season. After a total gestation of 7 months, a post-partum oestrus then occurs with an ensuing second gestation period of no more than 4 months.

Another interesting feature in the seasonally polyoestrous phyllostomatid group is expressed by both Carollia perspicillata and Glossophaga soricina. In these species at ovulation, menstruation occurs. The tubal journey of the zygote is prolonged (12-14 days) and embryonic development proceeds to the blastocyst stage in the oviduct. This may be a selective adaptation that permits regeneration of the uterine endometrium which is sloughed at ovulation (Rasweiler, 1972).

A number of tropical Old World species from the family Molossidae have been reported to be polyoestrous. Braestrup (1933) reported that several bats from the Congo Basin are polyoestrous (Mops congicus = Tadarida congicus, Nyctinomus ochraceus = Tadarida ochraceus, Mops trevori $=$ Tadarida trevori and Chaerephon russatus = Tadarida russatus). Marshall \& Corbett (1959) studied Chaerephon hinde (= Tadarida pumila) from equatorial East Africa and reported two annual breeding cycles which correlate with peak rainfall. This observation has been confirmed by Mutere (1973a) who described bimodal breeding coinciding with peak annual rainfall in the tropical molossid Tadarida condylura. In non-pregnant (young of the year) Tadarida pumila and Tadarida condylura, Mutere (1973a) noted that uterine horns were of equal size and appearance; however, when pregnant, implantation always occurred in the right horn. Harrison (1958) identified yet another Old World tropical (Tanganyika) polyoestrous molossid (Tadarida pumila websteri).

Seasonally monoestrous bats are represented by both mega- and microchiropteran populations. Included are the pteropids Pteropus geddiei and Pteropus eonotis (Baker \& Baker, 1936), Pteropus giganteus (Marshall, 1947), the megadermatid Megaderma lyra lyra (Gopalakrishna, 1950; Ramakrishna, 1951; Ramaswamy, 1962) and the vespertilionid Miniopterus australis (Richardson, 1977). In these species, a single young is born annually. However, only Megaderma expresses sinistral dominance. Also contained in the monoestrous group are a number of bats which exhibit unique reproductive specializations, some of which are similar to those noted for the polyoestrous species. For example, Eidolon helvum (Pteropidae) displays seasonal breeding; however, a 2-3 month delay exists between fertilization and actual implantation of the blastocyst (Mutere, 1965; Fayenuwo \& Halstead, 1974). In the microchiropteran species Noctilio albiventris (Noctilionidae) (Rasweiler, 1977) and Pipistrellus ceylonicus chrysothrix (Vespertilionidae) (Gopalakrishna \& Madhavan, 1971), spermatozoa can survive for extended periods (up to 5 weeks) in the female reproductive tract. The early embryonic development of the zygote as it travels through the oviduct that was observed in Carollia and Glossophaga is likewise expressed in Noctilio (Rasweiler, 1977).

Nonhibernating Macrotus californicus, a tropical New World insectivorous phyllostomatid bat, exhibits the unique specializations of delayed embryological development, as noted in the frugivorous phyllostomatid species Artibeus jamaicensis (Fleming, 1971), and ovarian and 
uterine dextral dominance (Bradshaw, 1962; Burns, Baker \& Bleier, 1972; Bodley, 1974; Bleier, 1975).

Tadarida brasiliensis, a North American member of the family Molossidae (free-tailed bats), demonstrates an equally specialized and interesting reproductive pattern. In this species, oestrous activities are reserved until the onset of spring. The spermatogenic and ovarian cycles are synchronized. Copulation, insemination, ovulation and fertilization usually occur between late February and mid-March and embryogenesis follows with parturition of the single young usually by late June or early July (Hartman, 1933; Sherman, 1937; Krutzsch, 1955a,b, 1959; Davis, Herreid \& Short, 1962). The family Molossidae demonstrates, throughout its virtually worldwide distribution, unusual morphological stability in arrangement of both male and female reproductive tracts. Molossids have marked right-left ovarian asymmetry with the right ovary always morphologically larger and, so far as is known, always serving as the gamete-producing organ. Likewise, the molossid bicornuate uterus displays a similar dextral dominant characteristic (Sherman, 1937; Hamlett, 1947; Krutzsch, 1955a; Davis et al., 1962; Krutzsch, 1964; Mutere, 1973a, b; Wimsatt, 1975).

Polyoestrous and aseasonal breeding appear to be the usual pattern for Old World tropical molossids; however, a monoestrous and seasonally breeding species, Otomops martiensseni, has also been observed (Mutere, 1973b). The reproductive pattern and morphology of this species is similar to that of the temperate molossids Eumops perotis (Krutzsch, 1955b), Tadarida brasiliensis cynocephala (Sherman, 1937; Stephens, 1962; LaVal, 1973) and Tadarida brasiliensis mexicana (Krutzsch, 1955a, 1959; Davis et al., 1962; Gutierrez \& Aoki, 1973). Kayanja \& Mutere (1975) also reported that the right ovary of Otomops martiensseni is the gamete-forming organ and that the left ovary appears to be atrophic. Similar observations were reported by Ruby \& Webster (1972) for the fetal ovarian ultrastructure of Tadarida brasiliensis cynocephala. These authors excluded the left ovary from their study because of apparent developmental differences between it and the right ovary.

Thus, although one-sided dominance of the reproductive tract has long been recognized as occurring throughout the family Molossidae (Sherman, 1937; Hamlett, 1947; Krutzsch, 1955b, 1964; Davis et al., 1962; Stephens, 1962; Mutere, 1973a, b; Wimsatt, 1975), the microscopic details correlating structure and function and the mechanisms determining and regulating such variation have not been reported. From ultrastructural evidence, Kayanja \& Mutere (1975) reported a steroidogenic capability for the interstitial cells in the larger right ovary of the tropical molossid Otomops martiensseni. Their study contains the only documented microscopic ovarian data available for the family Molossidae, although a description of the oestrous cycle and left ovary were not included. No other microscopic examination of the evidence for the ovarian asymmetry of the family Molossidae has been reported. The literature available for this family is scanty and no data have been reported for the physiology of the smaller left ovary of any molossid; therefore, the present study was undertaken.

\section{Materials and Methods}

A total of 296 female Mexican free-tailed bats, Tadarida brasiliensis mexicana, was used. They were obtained from their natural roosting places throughout southern Arizona from 1974 through 1977.

Bats were distinguished by age according to tooth wear (Hall, Cloutier \& Griffin, 1957) and interphalangeal joint development, weighed to the nearest $0.1 \mathrm{~g}$ and killed by decapitation. Blood was obtained from 111 bats and the sera were stored at $-20^{\circ} \mathrm{C}$ for subsequent radioimmunoassay procedures. The entire reproductive tracts were removed from 123 bats, freed of extraneous fat and connective tissue and processed for ultrastructural, histological and histochemical studies. 


\section{Light microscopy}

Reproductive organs from 107 adults were fixed in aqueous or alcoholic Bouin's fluid (Humason, 1967) for $24 \mathrm{~h}$ and embedded in paraffin wax. Serial sections were cut at $5 \mu \mathrm{m}$, were alternately stained with Delafield's haematoxylin and eosin, Mallory's trichrome, or periodic acid-Schiff techniques (Humason, 1967). The glycogen-hydrolysing capability of $\alpha$-amylase (Sigma Chemical Co., St Louis) on controls was confirmed by processing sections of glucoseloaded rat liver with sections from reproductive tracts.

\section{Enzyme histochemistry}

Reproductive organs (uterus, right and left ovaries) from 56 (4 fetal, 4 subadult and 48 adult) bats were frozen at $-20^{\circ} \mathrm{C}$ in Lipshaw M-1 embedding matrix and sectioned at $10 \mu \mathrm{m}$ in a Lipshaw Cryostat. Sections were placed on glass slides, air dried and processed for confirmation of steroidogenic activity. Using pregnenolone, dehydroepiandrosterone, oestradiol-17 $\beta$ and $20 \alpha-$ hydroxyprogesterone as substrates, the histochemical method for detection and localization of $\Delta^{5}-3 \beta-, 17 \beta-$, and $20 \alpha$-hydroxysteroid dehydrogenases (HSD) was adapted from those described by Altmann \& Chayen (1965), Baillie, Ferguson \& Hart (1966), Balogh (1964, 1966), Chayen, Bitensky, Butcher \& Poulter (1969) and Pearse (1972). Sections were incubated for $1 \mathrm{~h}$ at $37^{\circ} \mathrm{C}$ in a Tris-buffered medium with appropriate substrates and nitroblue tetrazolium. Incubations for NAD-dependent $\Delta^{5}-3 \beta$ - and $17 \beta$-HSD were performed at $\mathrm{pH} 7.2$ and for the NADP-dependent $20 \alpha$-HSD at pH 8.01. After incubation, sections were fixed in $10 \%$ neutral formalin, washed and counterstained in $2 \%$ aqueous methyl green. The intensity of diformazan reaction product was evaluated on a 0 to +++++ scale.

\section{Radioimmunoassay of progesterone}

A $50 \mu \mathrm{l}$ serum sample from each of 111 female bats obtained at intervals throughout the annual cycle was individually assayed for circulating progesterone according to the procedures outlined by Thorneycroft \& Stone (1972). The antibody used (1:15000 dilution) was produced against 11-hydroxyprogesterone-bovine serum albumin (Surve, Brinckerhoff \& Kirsch, 1976). Progesterone was extracted twice using fresh anhydrous diethyl ether. Separation of free and bound steroid was accomplished utilizing a charcoal-dextran suspension (100 $\mathrm{ml}$ glucosephosphate buffer; $250 \mathrm{mg}$ Norit A charcoal, fine particles removed; $25 \mathrm{mg}$ Dextran D-3759: Sigma Chemical, St Louis, Missouri) and then centrifuged at $4^{\circ} \mathrm{C}$ and $1550 \mathrm{~g}$ for $10 \mathrm{~min}$. Each supernatant was decanted into a scintillation vial containing $10 \mathrm{ml}$ scintillation cocktail $(100 \mathrm{~g}$ naphthalene, $8.0 \mathrm{~g}$ PPO, $0.3 \mathrm{~g}$ POPOP and $1000 \mathrm{ml}$ scintillation grade 1,4 dioxane) and counted in a Beckman LS-150 Liquid Scintillation System (Beckman Instruments, Inc., Fullerton, CA) with an efficiency of $35 \%$ for tritium. Sensitivity of the standard curve was determined to be 10 pg. Inter- and intra-assay coefficients of variation were $16 \%$ and $7 \%$ respectively. Ligand-free serum was also evaluated in order to establish significant minimal progesterone levels $(5.0$ $\mathrm{ng} / \mathrm{ml})$.

\section{Results}

\section{Light microscopic observations}

Right ovary. The representative preovulatory ovary (February) demonstrated an abundance of all types of follicles in various stages of development and atresia (Pl. 1, Fig. 1). Characteristically, primordial follicles and primary oocytes were congregated at the periphery of the cortex and intermingled with stromal cells. As the follicles matured from primary to tertiary states, they 
appeared to migrate from more cortical positions toward the medulla. The medulla appeared to function as a receptacle for follicles in advanced stages of atresia. Follicles undergoing atresia often possessed ova that showed a lattice work of coalescing cytoplasmic vacuoles while the remaining cytoplasm (if any) was located at the periphery.

Although a thin PAS-positive layer between the oocyte and flattened granulosa layer was observed in primordial follicles, the initial, well-defined zona pellucida was not apparent until the single layer of granulosa cells had achieved the cuboidal/columnar nature characteristic of a primary follicle. Once established, the zona pellucida remained at an average thickness of $1.5 \mu \mathrm{m}$ throughout follicular development.

A well-defined basement membrane enclosed all growing follicles that had progressed beyond the primordial state. External to the basement membrane of all developing follicles was a theca consisting of three to four flattened cell layers. This thecal layer could not be structurally separated into internal and external parts. Individual polygonally-shaped cells of the interstitial gland tissue contained a single centrally located nucleus with euchromatin and a single nucleolus. The eosinophilic cytoplasm was homogeneously granular. When not confined or compressed by other ovarian structures (i.e., follicles, corpus luteum), the interstitial cells were rounded with centrally placed nuclei. Mitotic figures were not observed in the interstitium. When the corpus luteum became established in early March at the onset of pregnancy, it was enclosed by a thecal layer which merged with and was indistinguishable from the surrounding interstitium. Individual luteal cells of early pregnancy were difficult to distinguish microscopically because they were packed tightly together. However, as gestation continued to mid-pregnancy, the luteal gland became richly vascularized and its cellular organization permitted microscopic visualization. Luteal cells had a single, rounded nucleus with a centrally placed nucleolus. These cells expressed a wide variety of cytoplasmic form randomly distributed throughout the gland. Staining intensity of the cytoplasm also varied widely from a smooth, homogeneous eosinophilia to a light, dusty, granular appearance. The nuclei of the neighbouring interstitial gland cells meanwhile showed an increase in condensed heterogeneity and the cytoplasm showed a corresponding increase in cytoplasmic granularity.

Left ovary. The structure of this ovary (Pl. 1, Fig. 3) was very similar to that of the right ovary except that follicles of more than $300 \mu \mathrm{m}$ in diameter and luteal tissue were not seen. The dominant cellular type was the interstitial tissue. The cells were usually polygonal or rounded

Table 1. Localization and relative intensity of $\Delta^{5}-3 \beta$-hydroxysteroid dehydrogenase in the ovaries (interstitial cells (IC), CL or theca) of adult Mexican free-tailed bats throughout the year

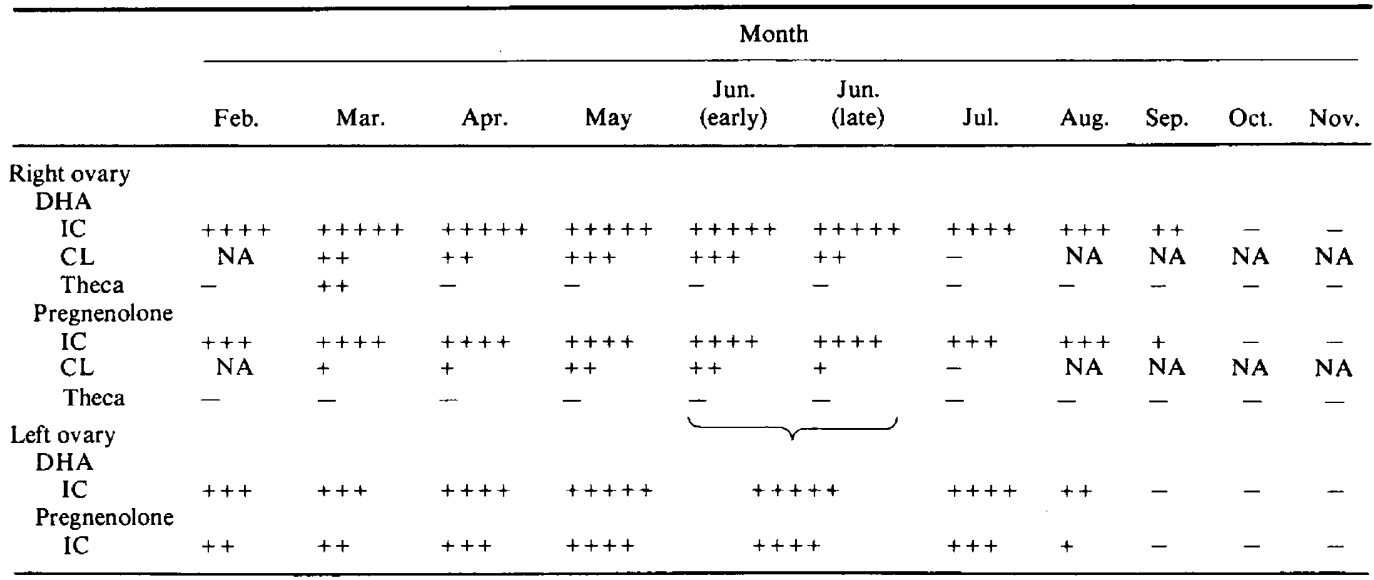

$+=$ presence, $-=$ absence, $\mathrm{NA}=$ secretory structure absent 
structures each with a centrally located euchromatic nucleus and a single nucleolus. The cytoplasm of these cells was eosinophilic and homogeneous and no mitotic figures were observed.

\section{Enzyme histochemical analysis}

Right ovary. Confirmation of the sites of steroidogenic activity in the right ovary of Tadarida involved the detection and localization of hydroxysteroid dehydrogenases, key enzymes in the steroid biosynthetic pathways. The reduction of a yellow soluble tetrazolium salt to an insoluble blue-black reaction product was observed when pregnenolone and dehydroepiandrosterone (DHA) were substrates but not detected when oestradiol-17 $\beta$ or $20 \alpha$ hydroxyprogesterone were the substrates. The results were expressed as a function of the intensity and site of deposition of diformazan precipitate using DHA or pregnenolone as substrates and NAD as cofactor (Table 1). Reaction product was at all times either localized in the interstitial gland tissue, the theca of the Graafian follicle just prior to rupture, or the luteal cells (Pl. 1, Fig. 2). When the dehydrogenase reaction product was unusually intense in the interstitium, granules could also be observed over some of the adjacent thecal cells.

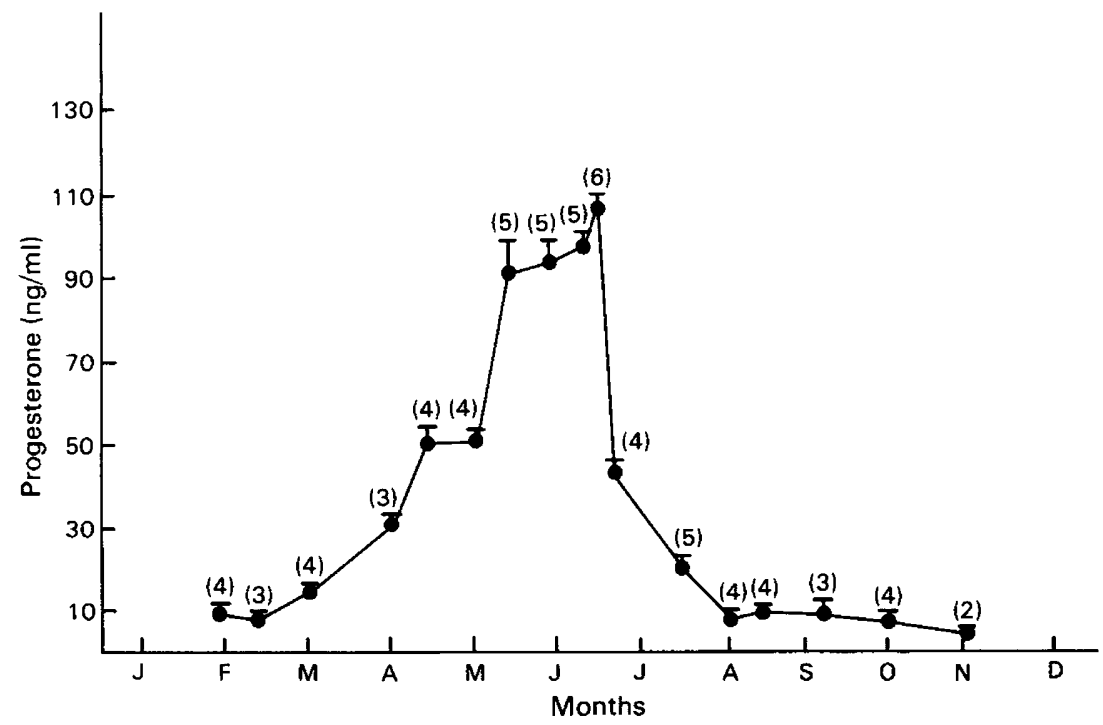

Text-fig. 1. Circulating concentrations of progesterone (mean \pm s.e.m., no. of observations in parentheses) in adult Mexican free-tailed bats throughout the year.

\section{EXPLANATION OF PLATE}

Fig. 1. Paraffin-wax section of an adult, pro-oestrous right ovary with its cortical and medullary zones. Note the numerous primordial follicles at the periphery of the cortex (arrows) and the growing follicles reflecting various stages of follicular development and atresia (F). H \& E, x64.

Fig. 2. Frozen section of an adult right ovary during pregnancy. Sites of localization and the intensity of the reaction product in the corpus luteum (CL) and interstitial gland tissue (IC) are noted. DHA, methyl green, $\times 160$.

Fig. 3. Paraffin-wax section through an adult left ovary during pro-oestrus. Note primordial follicles located most peripherally within the cortex. Maturing (MF) and atretic (AF) follicles are dispersed through the entire ovary. Interstitial gland tissue (IC) and vascular elements (arrows) comprise the majority of the ovary. PAS, $\times 80$.

Fig. 4. Frozen section through an adult left ovary during pro-oestrus. The reaction product is confined to the cells of the interstitial gland and does not involve cells of the granulosa $(\mathrm{Gn})$ and theca (Th). DHA, methyl green, $\times 80$. 

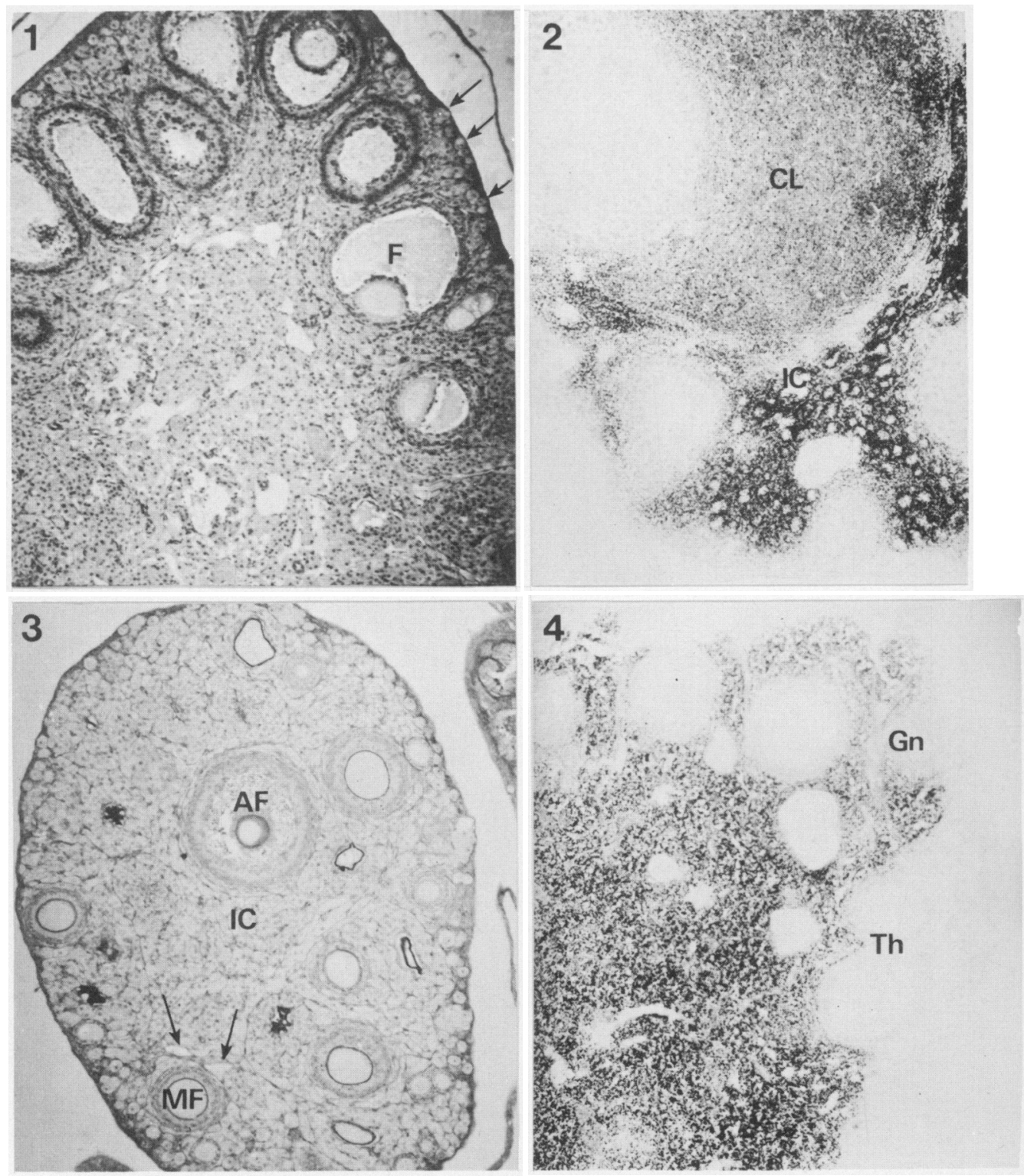
Left ovary. As with the right ovary, HSD activity (Pl. 1, Fig. 4) was only observed in the interstitial cells when DHA and pregnenolone were used as the substrates (Table 1). No reaction was seen in the thecal cells, whatever the substrate.

\section{Serum progesterone concentrations}

The results are shown in Text-fig. 1. At the onset of pregnancy (early March), an increase in progesterone levels occurred that correlated with the initial appearance of the corpus luteum. Progesterone levels continued to rise throughout pregnancy (peaking at $106 \mathrm{ng} / \mathrm{ml}$ in late June) but dropped dramatically at parturition (early July) and the simultaneous involution of the corpus luteum. Progesterone then returned to baseline levels with the cessation of lactation (midAugust) and remained at this level throughout dioestrus (September-February).

\section{Discussion}

The female reproductive tract of nonparous adult Tadarida brasiliensis mexicana is dextrally dominant. The asymmetrical bicornuate nature of the uterus is established early in life (approximately 8 months after birth) concurrent with the onset of the first oestrus. This observation seems to contradict that of Stephens (1962), who reported that the uterine horns are bilaterally symmetrical in Tadarida brasiliensis cynocephala. It is more likely, however, that Stephens (1962) based his observations upon young bats before their first oestrus. Bilaterally symmetrical uterine horns are characteristic for young of the year of all molossids examined so far, including Tadarida pumila, Tadarida condylura (Mutere, 1973a), Molossus ater, and Molossus fortis (P. H. Krutzsch, unpublished). Tadarida b. mexicana conforms to this pattern from its fetal development through the subadult period.

The Mexican free-tailed bat is a monotocous and monoestrous species in which the blastocyst almost invariably implants in the right uterine cornu. This observation agrees with those presented by other investigators of this species (Krutzsch, 1955a; Davis et al., 1962) and the closely related subspecies Tadarida b. cynocephala (Sherman, 1937). Concomitant with implantation there is uterine endometrial hypertrophy. Preimplantation hypertrophy in most mammals characteristically involves the entire endometrium (Reynolds, 1965). In Tadarida $b$. mexicana only the right horn displays increased vascularity and hyperplastic glandular development. Both horns have PAS-positive material (glycogen) in the apical margin of the endometrial epithelium. Similar unilateral hypertrophy has been confirmed for Tadarida $b$. cynocephala (Stephens, 1962) and by Marshall (1953) for the giant fruit-bat Pteropus giganteus. Marshall (1953) reported an isthmus of tissue connecting the right ovary to its adjacent uterine horn through which small blood vessels pass, suggesting the possibility of direct steroid stimulation. Stephens (1962) noted no structure which might provide preferential distribution of luteal or other ovarian steroid hormones to the distal end of the right uterine horn of Tadarida $b$. cynocephala. However, he suggests that the differential uterine development is the result of a difference in the responsiveness of the two uterine horns to circulating levels of oestrogen and progesterone. This hypothesis could easily be tested in Tadarida $b$. mexicana by ascertaining the presence of receptor sites in uterine tissue.

Recently, Channing \& Coudert (1976) identified the thecal component of the large preovulatory follicle of the rhesus monkey as the principal source of ovarian venous oestrogen. Although cannulating ovarian venous effluent was not attempted in Tadarida, $\Delta^{5}-3 \beta$-hydroxysteroid dehydrogenase activity has been detected in the thecal compartment of the single Graafian follicle at a time when the surrounding interstitial gland has an intense reaction product (see Table 1). The steroidogenic capability of the theca is lost with the establishment of the 
corpus luteum which is enclosed by the distinctive thecal component. Although $17 \beta-\mathrm{HSD}$, an indicator of oestrogens, could not be detected in the thecal compartment of the Graafian follicle, it is possible that the enzyme concentrations are below the sensitivity of this assay.

The enzyme $\Delta^{5}-3 \beta$-HSD has been localized in the ovary of a variety of mammalian types (Baillie et al., 1966; Blaha \& Leavitt, 1970; Motta \& Takeva, 1971; Saidapur \& Greenwald, 1978) and serves as an indicator of steroidogenic activity. This established technique provides an additional means of pinpointing specific cellular sites of steroidogenesis in the Tadarida ovary. The reaction product using pregnenolone and dehydroepiandrosterone as substrates (Table 1) provides evidence that the interstitium possesses the capacity to synthesize progesterone and/or suggests an aromatizing capability by the interstitial gland cells to produce androgens, as noted by Saidapur \& Greenwald (1978).

Although measurement of progesterone by radioimmunoassay has previously been recorded in a variety of mammalian species (e.g. man: Thorneycroft \& Stone, 1972; rabbit: Challis, Davies \& Ryan, 1973; ewe: Hartmann, Trevethan \& Shelton, 1973; mink: Møller, 1973; hamster: Baranczuk \& Greenwald, 1974; mouse: McCormack \& Greenwald, 1974; pig: Robertson \& King, 1974; dog: Edqvist, Johansson, Kasstrom, Olsson \& Richkind, 1975), it is only recently that plasma has been measured in bats (Burns \& Easley, 1977). The peak value of $28 \mathrm{ng} / \mathrm{ml}$ of Burns \& Easley (1977) agrees with those reported for the ewe (Hartmann et al., 1973) $(28 \mathrm{ng} / \mathrm{ml})$, but P. H. Krutzsch (unpublished observations) and Oxberry (1979) found individual high values of 119 and $55 \mathrm{ng} / \mathrm{ml}$ just before parturition in Macrotus californicus and Antrozous pallidus pallidus respectively. These data more closely reflect the mean progesterone peak of $106 \mathrm{ng} / \mathrm{ml}$ observed just before parturition in Tadarida b. mexicana (see Text-fig. 1). At parturition, progesterone levels drop abruptly and continue to decline gradually until the cessation of lactation. Other indicators of reduced progesterone synthesis and secretion were the decrease in intensity of reaction product in the degenerating corpus luteum and interstitial gland tissue (Table 1). A baseline value of circulating plasma progesterone $(5 \mathrm{ng} / \mathrm{ml}$ ) when no luteal tissue is present implicates the interstitial tissue as a possible compartment for progesterone synthesis.

\section{References}

Altman, F.P. \& Chayen, J. (1965) The significance of a functioning hydrogen-transport system for the retention of 'soluble' dehydrogenases in unfixed sections $J$. Roy. microsc. Soc. 85, 175-180.

Asdell, S.A. (1964) Patterns of Mammalian Reproduction. Cornell Univ. Press, Ithaca, $670 \mathrm{pp}$.

Baillie, A.H., Ferguson, M.M. \& Hart, D.McK. (1966) Developments in Steroid Histochemistry. Academic Press, London.

Baker, J.R. \& Baker, Z. (1936) The seasons in a tropical rain forest (New Hebrides). Part II. Fruit bats (Pteropidae). J. Linn. Soc. Lond. 40, 123-141.

Balogh, K. (1964) A histochemical method for the demonstration of $20 a$-hydroxysteroid dehydrogenase activity in rat ovaries. J. Histochem. Cytochem. 12, $670-673$.

Balogh, K. (1966) Histochemical demonstration of $3 \beta$ hydroxysteroid dehydrogenase activity. J. Histochem. Cytochem. 14, 77-83.

Baranczuk, R. \& Greenwald, G.S. (1974) Plasma levels of oestrogen and progesterone in pregnant and lactating hamsters. J. Endocr. 13, 125-135.
Blaha, G.C. \& Leavitt, W.W. (1970) The distribution of ovarian $\Delta^{5} 3 \beta$-hydroxysteroid dehydrogenase activity in the golden hamster during the estrous cycle, pregnancy and lactation. Biol. Reprod. 3, 362 368 .

Bleier, W.J. (1975) Crystalline structure in the ova and early embryological stages in a leaf-nosed bat, Macrotus Californicus. J. Mammal. 56, 235-238.

Bodley, H.D. (1974) Ultrastructural development of the chorioallantoic placental barrier in the bat, Macrotus waterhousii. Anat. Rec. 180, 351-367.

Bonilla, H. \& Rasweiler, J.J. (1974) Breeding activity, preimplantation development, and oviduct histology of the short tailed fruit bat, Carollia, in captivity. Anat. Rec. 179, 385-404.

Bradshaw, G.V.R. (1962) Reproductive cycle of the California leafnosed bat, Macrotus californicus. Science, N.Y. 136, 645-646.

Braestrup, F.W. (1933) On the taxonomic value of the subgenus Lophomops (Nyctinomine Beta), with remarks on the breeding times of African bats. Ann. Mag. Nat. Hist. 11, 269-274. 
Burns, J.M., Baker, R.J. \& Bleier, W.J. (1972) Hormonal control of 'delayed development' in Macrotus waterhousii. Gen. comp. Endocr. 18, 54-58.

Burns, J.M. \& Easley, R.G. (1977) Hormonal control of delayed development in the California leaf-nosed bat, Macrotus californicus. Gen. comp. Endocr. 32, 163166.

Challis, J.R.G., Davies, I.J. \& Ryan, K. (1973) The concentrations of progesterone, estrone and estradiol-17 $\beta$ in the plasma of pregnant rabbits. Endocrinology 93, 971-976.

Channing, C.P. \& Coudert, S.P. (1976) Contribution of granulosa cells and follicular fluid to ovarian estrogen secretion in the rhesus monkey in vivo. Endocrinology 98, 590-597.

Chayen, J., Bitensky, L., Butcher, R.G. \& Poulter, L.W. (1969) A Guide to Practical Histochemistry. Oliver and Boyd, Edinburgh.

Davis, R.B., Herreid, C.F. \& Short, H.L. (1962) Mexican free-tailed bats in Texas. Ecological Monographs 32, 311-346.

Edqvist, L.E., Johansson, E.D.B., Kasstrom, J., Olsson, S.E. \& Richkind, M. (1975) Blood plasma levels of progesterone and oestradiol in the dog during the oestrous cycle and pregnancy. Acta endocr. Copenh. 78, 554-564.

Fayenuwo, J.O. \& Halstead, L.B. (1974) Breeding cycle of straw-colored fruit bat, Eidolon helvum, at Ile-Ife, Nigeria. J. Mammal. 55, 453-454.

Fleming, T.H. (1971) Artibeus jamaicensis: delayed embryonic development in a neotropical bat. Science, N.Y. 171, 402-404.

Fleming, T.H., Hooper, E.T. \& Wilson, D.E. (1972) Three Central American bat communities: structure, reproductive cycles, and movement patterns. Ecology $53,555-568$.

Gopalakrishna, A. (1950) Studies on the embryology of Microchiroptera. Part VI. Structure of the placenta in the Indian vampire bat, Lyroderma lyra lyra (Geoffroy). (Megadermatidae). Proc. natn. Inst. Sci. India 16,93-98.

Gopalakrishna, A. (1955) Observations on the breeding habits and ovarian cycle in the Indian sheath-tailed bat, Taphozous longimanus (Hardwicke). Proc. natn. Inst. Sci. India 21, 29-39.

Gopalakrishna, A. \& Choudhari, P.N. (1977) Breeding habits and associated phenomena in some Indian bats. Part I-Rousettus leschenaulti (Desmarest) Megachiroptera. J. Bombay nat. Hist. Soc. 74, 1-16.

Gopalakrishna, A. \& Madhavan, A. (1971) Survival of spermatozoa in the female genital tract of the Indian vespertilionid bat, Pipistrellus ceylonicus chrysothrix (Wroughton). Proc. Indian Acad. Sci. 73, 43-49.

Gopalakrishna, A. \& Murthy, K.V.R. (1960) Uteroovarian junction in two species of bats. Bull. zool. Soc., Nagpur Coll. Sci. 3, 19-21.

Gopalakrishna, A., Thakur, R.S. \& Madhavan, A. (1975) Breeding biology of the southern dwarf pipistrelle, Pipistrellus mimus mimus (Wroughton) from Maharashtra, India. Commemorative Volume for Dr B. S. Chauhan, pp. 225-240.

Gutierrez, M. \& Aoki, A. (1973) Fine structure of the gular gland of the free-tailed bat Tadarida brasiliensis. J. Morph. 141, 293-306.
Hall, J.S., Cloutier, R.J. \& Griffin, D. (1957) Longevity records with notes on tooth wear of bats. $J$. Mammal. 38, 407-409.

Hamlett, G.W.D. (1947) Embryology of the molossid bat, Eumops. Anat. Rec. 97, 340-341.

Harrison, D.L. (1958) A note on successive pregnancies in an African bat, Tadarida pumila websteri (DoIman). Mammalia 22, 592-594.

Hartman, C.G. (1933) On the survival of spermatozoa in the female genital tract of the bat. $Q$. Rev. Biol. 8 , 185-193.

Hartmann, P.E., Trevethan, P. \& Shelton, J.N. (1973) Progesterone and oestrogen and the initiation of lactation in ewes. J. Endocr. 59, 249-259.

Humason, G.L. (1967) Animal Tissue Techniques. W. H. Freeman and Co., San Francisco.

Kayanja, F.I.B. \& Mutere, F.A. (1975) The ovary of the insectivorous bat, Otomops martiensseni. Anat. Anz. 137, 166-175.

Krutzsch, P.H. (1955a) Observations on the Mexican free-tailed bat, Tadarida mexicana. J. Mammal. 36, 236-242.

Krutzsch, P.H. (1955b) Observations on the California mastiff bat. J. Mammal. 36, 407-414.

Krutzsch, P.H. (1959) The reproductive cycle of the male Mexican free-tailed bat, Tadarida brasiliensis mexicana. Anat. Rec. 133, 400.

Krutzsch, P.H. (1964) The reproductive cycle of the male bat of the species Pipistrellus subflavus. Anat. Rec. 148, 303.

Laval, R.K. (1973) Observations on the biology of Tadarida brasiliensis cynocephala in southeastern Louisiana. Am. Midl. Nat. 89, 112-120.

Liat, L.B. (1970) Food habits and breeding cycle of the Malaysian fruit-eating bat, Cynopterus brachyotis. $J$. Mammal. 51, 174-177.

Marshall, A.J. (1947) The breeding cycle of an equatorial bat (Pteropus giganteus) of Ceylon. Proc. Linn. Soc. Lond. 159, 103-111.

Marshall, A.J. (1953) The unilateral endometrial reaction in the giant fruit-bat (Pteropus giganteus Brunnich). J. Endocr. 9, 42-44.

Marshall, A.J. \& Corbett, P.S. (1959) The breeding biology of equatorial vertebrates: reproduction of the bat Chaerephon hindei thomas at latitude $0^{\circ} 26^{\prime} \mathrm{N}$. Proc. zool. Soc. Lond. 132, 607-616.

McCormack, J.T. \& Greenwald, G.S. (1974) Progesterone and oestradiol-17 $\beta$ concentrations in the mouse. J. Endocr. 62, 101-107.

Møller, O.D. (1973) The progesterone concentration in the peripheral plasma of the mink (Mustela vison) during pregnancy. J. Endocr. 56, 121-132.

Motta, P. \& Takeva, Z. (1971) Histochemical demonstration of $\Delta^{s}-3 \beta$-hydroxysteroid dehydrogenase activity in the interstitial tissue of the guinea pig ovary during the estrous cycle and pregnancy. Fert. Steril. 22, 378-382.

Mutere, F.A. (1965) Delayed implantation in an equatorial fruit bat. Nature, Lond. 207, 780 .

Mutere, F.A. (1968) The breeding biology of the fruit bat Rousettus aegyptiacus $\mathrm{E}$. Geoffrey living at $0^{\circ} 22^{\prime} \mathrm{S}$. Acta trop. 25, 97-108.

Mutere, F.A. (1973a) Reproduction in two species of equatorial free-tailed bats (Molossidae). East Afr. Wild. J. 2, 271-280. 
Mutere, F.A. (1973b) A comparative study of reproduction in two populations of the insectivorous bats, Otomops martiensseni, at latitudes $1^{\circ} 5^{\prime} \mathrm{S}$ and $2^{\circ} 30^{\prime}$ S. J. Zool., Lond. 171, 79-92.

Okai, N.O. (1974a) Breeding in Franquet's bat, Epomops franquetti (Tomes), in Uganda. J. Mammal 55, 462465.

Okia, N.O. (1974b) The breeding pattern of the eastern epauletted bat, Epomophorus anurus Heuglin, in Uganda. J. Reprod. Fert. 37, 27-31.

Oxberry, B.A. (1979) Female reproductive patterns in hibernating bats. J. Reprod. Fert. 56, 359-367.

Pearse, A.G.E. (1972) Histochemistry, Theoretical and Applied. Williams and Wilkins Co., Baltimore.

Quintero, F. \& Rasweiler, J.J. (1974) Ovulation and early embryonic development in the captive vampire bat, Desmodus rotundus. J. Reprod. Fert. 41, 265273.

Ramakrishna, R.A. (1951) Studies on the reproduction in bats I-Some aspects of the reproduction in the Oriental vampires, Lyroderma lyra lyra (Geoffroy) and Megaderma spasma (Linn.). Half-yrly J. Mysore Univ. 11, 107-118.

Ramaswamy, K.R. (1962) Studies on the sex-cycle of the Indian vampire bat, Megaderma (Lyroderma) lyra lyra (Geoffroy). Proc. natn. Inst. Sci. India 27, 287307.

Rasweiler, J.J. (1972) Reproduction in the long-tongued bat, Glossophaga soricina. I. Preimplantation development and histology of the oviduct. $J$. Reprod. Fert. 31, 249-262.

Rasweiler, J.J. (1974) Reproduction in the long-tongued bat, Glossophaga soricina. II. Implantation and early embryonic development. Am. J. Anat. 139, 136.

Rasweiler, JJ. (1977) Preimplantation development, fate of the zona pellucida, and observation on the glycogen-rich oviduct of the little bulldog bat, Noctilio albiventris. Am. J. Anat. 150, 269-300.
Reynolds, S.M.R. (1965) Physiology of the Uterus. Hafner Publishing Co, New York.

Richardson, E. (1977) The biology and evolution of the reproductive cycle of Miniopterus schreibersii and M. australis (Chiroptera: Vespertilionidae). J. Zool., Lond 183, 353-375.

Robertson, H.A. \& King, G.J. (1974) Plasma concentrations of progesterone, oestrone, oestradiol-17 $\beta$ and of oestrone sulphate in the pig at implantation, during pregnancy and at parturition. J. Reprod. Fert. 40, $133-141$

Ruby, J.R. \& Webster, R.M. (1972) Origin of the golgi complex in germ cells in the developing ovary of the bat. Z. Zellforsch. mikrosk. Anat. 133, 1-12.

Saidapur, S.K. \& Greenwald, G.S. (1978) Sites of steroid synthesis in the ovary of the cyclic hamster: a histochemical study. Am. J. Anat. 151, 71-86.

Sherman, H.B. (1937) Breeding habits of the free-tailed bat. J. Mammal. 18, 176-187.

Stephens, RJ. (1962) Histology and histochemistry of the placenta and fetal membranes in the bat, Tadarida brasiliensis cynocephala (with notes on maintaining pregnant bats in captivity). Am J. Anat. $111,259-286$.

Surve, A.H., Brinckerhoff, J.H. \& Kirsch, S.J. (1976) Plasma levels of progesterone in pseudopregnant rabbits actively immunized with a progesterone-protein conjugate. Biol. Reprod. 15, 129146.

Thorneycroft, I.H. \& Stone, S.C. (1972) Radioimmunoassay of serum progesterone in woman receiving oral contraceptive steroids. Contraception 5, 129146.

Wimsatt, W.A. (1975) Some comparative aspects of implantation. Biol. Reprod. 12, 1-40.

Wimsatt, W.A. \& Trapido, H. (1952) Reproduction and the female reproductive cycle in the tropical American vampire bat, Desmodus rotundus murinus. Am.J. Anat. 91, 415-446. 